\title{
Kaleidoscope
}

\author{
ZAID Ali ZAID*
}

\section{Humanitarian intervention in international law}

\begin{abstract}
The concept of humanitarian intervention evolved as a subset of laws that govern the use of force and now, it occupies an institutional position alongside Security Council authorization and self-defense as a legitimate and legal reason for war. Humanitarian intervention and use of force both are highly controversial yet widely accepted. This paper will evaluate whether humanitarian intervention is legitimate under international law. Humanitarian intervention contradicts the United Nations Charter but state practice developments since the Second World War have made it legitimate under a number of circumstances. Those who have argued for its legitimacy cite international norms and state practice to support the assertion that the provision for military aggression is no longer what is enshrined in the UN Charter. The debate on the legality of humanitarian intervention indicates that it could either be legitimate or illegitimate depending on how one comprehends the construction, changing and representation of international law. It is certain that there are no definite answers to these questions. This uncertainty is now fundamental since the legitimacy of humanitarian intervention is indeterminate. Discussions over this law have not solved this puzzle. It remains legal and illegal at the same time, with recent cases not withstanding depending with the circumstances. This paper evaluates the repercussions of this finding for the sake of the rule of law in world politics. The paper suggests that customary prominence that scholars place on compliance with international law is misplaced. The power of international law from scholars' point of view comes from its capacity to shape the terrain for balance of political power in international relations rather than differentiating rule followers and rule breakers. International law should be perceived as a resource for state use rather than a fixed standard of evaluating behavior.
\end{abstract}

Keywords: human rights, military action, domestic affairs, international relations, sovereignty, cross border.

\section{Introduction}

The humanitarian intervention legal status provides an insightful challenge to the future's global order. The central question could be easily formulated but very difficult to be answered. There is still no consensus as to whether international law should permit countries to militarily intervene to avert genocide or any atrocity of similar magnitude without the authorization of the Security Council. This question became critical in the wake of interventions of the military in Iraq and Kosovo while there was no intervention in Sudan. An impasse has so far been reached after concerted deliberations on these issues were made. A major obstacle to the legalization of unilateral humanitarian interventions is an effort by certain nations who would want to use it in the pretext of waging war with ulterior motives.

The concerns that states can exploit a humanitarian exception in order to justify military aggression have for a long time dominated government and academic debates. This

* Ph.D., Professor Assistant at Sharjah University, Division of Law, P. o. Box 27272, United Arab Emirates.

E-mail: zaidlibya@gmail.com 
concern pits values of a humanitarian rescue against the shock of expanded opportunities for an unrestrained war. Those who have been proposing that humanitarian intervention should be legalized have always struggled with the question of people objecting their proposals on the grounds that they would be abused in a pretext for war. The late 19th century saw these proponents be so influential and this was a period in which the international law allowed states to utilize war on several grounds.

This debate has been lost by these proponents in the current era because at various points, the terms of discussion have tended to shift. NATO's intervention in Kosovo spurred one of the most far-fetched discussions about the credibility of humanitarian intervention and the ability to have it regulated in the post-Cold War period. However, most governments' consensus on humanitarian interventions favors a case where there is Security Council intervention.

The intervention in the domestic affairs of a state that is sovereign by another state with the same status is one of the hottest debates in the current international law. This debate is hot because there is an ascendancy of cases of human rights abuse yet international law, right from the very beginning, held strongly the concept of sovereignty as its major tenet. Thus, the issue of non-interference was and is still held in high esteem by many countries. As a matter of fact, it is the concept of sovereignty that has been perceived on international diplomatic level as the bedrock of international relations.

Nevertheless, the doctrine of Unilateral Humanitarian Intervention (UHI) allows countries to intervene in the domestic affairs of other countries in case there are massive violations of human rights particularly in the form of genocide and mass murder. The humanitarian intervention doctrine is thus, an affront to one of the key tenets of international law that is non-interference and because of this, its validity has been hotly contested. This paper evaluates the doctrine of UHI and its legality.

\section{State sovereignty and the non-intervention principle}

According to Shen, ${ }^{1}$ for the last 20 decades, it is state sovereignty that has defined tenets of international relations thus, acting as a foundation of world order. This concept is amongst the fundamental principles of international law, both under customary international law and the United Nations Charter. Apart from that, it plays a very critical role in the upholding of international security and peace while acting as a defense of states that are weak against those that are strong. ${ }^{2}$

According to Fonteyne ${ }^{3}$, state sovereignty refers to the legal equality, competence and independence of states. Within this concept are all matters that all countries are allowed by the international law to act without compromising the sovereignty of other nations. Examples of such matters include the social, political, economic and cultural systems to be employed by the states. In these important issues, a state has free will to choose the way forward for its citizens without cohesion from any other state.

1 Shen, J.: The Non-Intervention Principle and Humanitarian Interventions under International Law. International Legal Theory, 7 (2001) 1.

2 Reisman, M.: Sovereignty and Human Rights in Contemporary International Law. American Journal of International Law, 84 (1990), 867.

3 Fonteyne, J.: The Customary International Law Doctrine of Humanitarian Intervention. California Western International Law Journal, 4 (1974), 203, 257. 
However, several scholars in international law contend that the current formulation of international law, as far as sovereignty is concerned, was highly influenced by the 1648 European agreement in the Westphalia treaties. ${ }^{4}$ The sovereign authority superiority was established within a system of equal and independent states in order to avoid another war after the First World War which led to the establishment of peace and order in Europe. It is critical to know the pertinent elements of statehood since for any entity to claim rights of statehood, it must be a state in itself. The Montevideo Convention stipulated the essential elements of a state. These include having a functioning government, a permanent population and a defined territory. ${ }^{5}$

According to Wright, ${ }^{6}$ the United Nations charter distinguishes state sovereignty as one of the key tenets of international law. This charter thus, adopted the principle of sovereignty equally amongst all states. Flowing from the critical nature of equality of all states, the charter sought to prevent the interference in the sovereignty of one country by another sovereign country. The charter went on in its efforts to protect states sovereignty to assert that nothing contained in its current charter shall allow the United Nations to intervene in matters that are occurring within the domestic jurisdiction of a state neither shall they require members of such a country to submit issues for settlement under the current charter. As a matter of fact, not even this world governing body has the authority to interfere in the sovereignty of any given state.

The International Court of Justice (ICJ), the principal judicial organ of the United Nations, recognized the sanctity of the tenet of non-interference in the domestic affairs of states. ${ }^{7}$ For example, in 1949 , the Court pointed out that the respect for territorial sovereignty between states that are independent is a critical foundation for international relations. ${ }^{8}$ Three decades later, the Court asserted that the principle of non-interference was the critical precept of state sovereignty on which the entire international law rests. ${ }^{9}$

\section{Unilateral humanitarian intervention (UHI)}

In international law, intervention refers to prohibited intervention. There are three forms of intervention depending on the level of cohesion used to interfere with other states. In the first description, intervention means recommendatory action, discussion or examination. In the second description, it means taking up cohesive measures but being short of using force, while in the third description, it means the use of force while interfering with the sovereignty of another country.

Humanitarian intervention has been defined as the justifiable use of force to protect citizens of a foreign nation against so persistent and arbitrary abuse as to go beyond the limit by which the sovereign nation is presumed to act within justice and reasons. It is presumed

${ }^{4}$ Gordon, E.: Article 2(4) in Historical Context. Yale Journal of International Law, 10 (1985), 270, 275.

5 Krasner, S. D.:Compromising Westphalia. International Security, 20 (1995-6), 115.

6 Wright, G. R.: A Contemporary Theory of Humanitarian Intervention. Florida International Law Journal, 4 (1989) 435.

7 Asylum Case, I.C.J. Reports 1949, 4.

${ }^{8}$ I.C.J. Reports 1949, 35.

9 Simon, S. G.: The Contemporary Legality of Humanitarian Intervention. California Western International Law Journal, (1993) 24, 117, 118. 
to be the theory of intervention on humanity grounds that recognizes a state's rights to exercise through military force international control over acts of another states regarding its internal sovereignty when its actions are deemed to contradict the laws of humanity.

Humanitarian intervention can also be described as the proportionate trans-boundary assistance which does not rule out forcible help provided by governments to individuals in other states who have been denied the basic human rights and who would be rationally willing at that point in time to revolt against the status quo of their oppressing governments. These definitions shed light on important factors that must be understood and identified in order to fully understand all issues involved in the doctrine. Armed force intervention is a common feature of the above descriptions. The justification on the use of force depends on the violations of human rights in the targeted state. For there to be prohibition of an intervention, there must be the use of cohesive means and the intervention's ends must be to influence the decisions of another state in matters that are within the jurisdiction of that particular state. ${ }^{10}$

\subsection{Reasons for Humanitarian Intervention}

The main purposes for humanitarian interventions is to avert the mass murder of civilian populations through acts such as genocide, by persons wielding state power against their own citizens, for instance, the escalating crisis in Syria wherein 50,000 so far have lost their lives. Since the year 1900, it is estimated that holders of state power have killed over 170,000 thousand of their own citizens. This number exceeds that of lives lost through wars fought in this century. Humanitarian actions have been taken in several of these cases to avert further abuses of human rights.

According to Farooq, ${ }^{11}$ the Idi Amin government committed acts of atrocity against its own citizens between 1971 to 1979. After uncovering torture, executions and rape committed by the Ugandan government, the Amnesty International characterized Idi Amin's regime as atrocious. In 1979, neighbouring Tanzania intervened on humanitarian grounds though it is argued they had ulterior motives. ${ }^{12}$

According to Franck and Rodley, ${ }^{13}$ India intervened in East Bengal (now Bangladesh) so as to avert more human rights violations. This was after the Pakistan Army had descended on the Bangladesh population in an orgy of destruction, killing and terror. India's timely intervention stopped atrocities on a wide scale. It cited cross border and human rights violations of West Pakistan as the reasons for their intervention. On the other hand, critics argue that India had other ulterior motives in their inversion. That is, to split up and weaken a powerful rival and thus enhances its own security. As much as most of these interventions have been touted as not genuine, the humanitarian concern they elicited justified their actions. ${ }^{14}$

10 Reisman, M.: Humanitarian Intervention and Fledgling Democracies. Fordham International Law Journals, 18 (1995), 794.

${ }^{11}$ Farooq, S.: Realpolitik In International Law: After Tanzanian-Ugandan Conflict "Humanitarian Intervention" Reexamined. Willamette Law Review, 17 (1981), 859, 881.

12 Schacter, O.: International Law: The Right of States to Use Armed Force. Michigan Law Review, 82 (1984), 1620.

13 Franck, M.-Rodley, N. S.: After Bangladesh: The Law of Humanitarian Intervention by Military Force. American Journal of International Law, 67 (1973), 275.

14 Reisman, M.: Criteria for the Lawful Use of Force in International Law. Yale Journal of International Law, 10 (1985), 279. 


\section{Maintenance of Regional and Global Security}

The maintenance of regional and global security is another justification for humanitarian interventions worldwide. Once a state becomes insecure due to atrocities such as genocide, the global and regional security is threatened. This is mainly because of refugees fleeing from their country to other regions in order to save their lives. For instance, the Indian intervention in Bangladesh was because lots of refugees fleeing atrocities such as mass murders and rape committed by the Pakistan Army were getting into India. About 10 million refugees found their way into India causing tremendous difficulty.

According to Moore, ${ }^{15}$ the organization of East Caribbean states (OECS) helped the USA in intervening in Grenada in 1983. the organization of East Caribbean states (OECS) helped the USA in intervening in Grenada in 1983. As much as the USA participation in the intervention was to free its own citizens, the OECS felt the break down in government and the civil unrest could become a security threat to their regional stability, thus, decided to use force to ensure there was peace in the region. Thus, this was their justification to assist the USA in the Grenada intervention.

Apart from these humanitarian interventions there is a tendency of dictators thinking they are so powerful that they can attack other nations. Hitler thought so and started attacking his neighbouring countries-the result of this was the Second World War.

\section{Historical developments of the UHI Principle}

\subsection{The law of nature}

The law of nature came as a result of philosophical underpinnings of a number of basic norms both moral and legal. It is essential according to the law of nature that all human beings, despite their background, shall be treated equally. Thus, this law can be regarded as the bedrock of the concept of natural human rights. It is this law that constituted the rational concept of a political society and formed the basis on which state sovereignty and social contract theory were founded in the early civilization. ${ }^{16}$

\subsection{Just war theories}

The principle of humanitarian intervention is strongly tied historically to the moral political theory of just war. The ancient Greeks felt that there was no need of waging war unless there was a cause to justify it. The Christian church was pacifist in its formative years and refused any justifications of war regardless of the circumstances.

\subsection{Interventions in the 19th and early 20th century}

Because of the strict application of the doctrine of nation state sovereignty, the 19th century was the recognition of conquests and unlimited right of war. The emergence of the balance of power brought these wars to an end. War was deemed a measure of last resort after all peaceful means of solving a dispute had failed. However, state practices did not reflect the

15 Moore, J. N.: Grenada and the International Double Standard. American Journal of International Law, 78 (1984), 145, 148.

16 Verwey, W. D.: Humanitarian Intervention under International Law. Netherlands International Law Review, 32 (1985), 357, 399-71. 
attitude of the world towards war and there arose issues of war, but not real war such as pacific blockade, self-defense and reprisals.

The practice of lesser use of force eventually evolved to include interventions warranted on humanitarian grounds. This started by the invasion of Greece by a number of western powers in 1827 to protect Christians from the persecution by Turks. The Treaty of London, which authorized the invasion asserted that it was approved by humanity sentiments. ${ }^{17}$

In the same breath, Russia intervened in Bulgaria, Bosnia and Herzegovina in 1877 while it was under the Ottoman Empire. The treatment meted out to the Christians here was so cruel that a British investigator described it as the most heinous crimes that had destroyed that century's history. The intervention was alleged to have been carried out on humanitarian grounds.

The 1898 US invasion of Cuba was also said to have happened on humanitarian grounds. While addressing the US Congress, President McKinley asserted that the invasion's objective was for humanitarian reasons in order to halt the horrible miseries, barbarities, starvation and bloodshed that already existed there. A number of leading scholars in international law doubt the genuine nature of these interventions. They point out that as much as they were purported to have solely been carried out on humanitarian grounds power, politics between European states and western states also played a role. Consequently, in this period of time, there has been no clear case of humanitarian interventions.

In the early 20th century, there occurred a subsiding of the desire to intervene for humanitarian purposes and the unilateral use of force was perceived to be illegal. The creation of the League of Nations provided institutional guarantees of certain rights and the league was given the mandate to authorize the collective use of force in some cases. The Covenant of the League of Nations signed in 1919 wanted to prohibit States from going to war but did not abolish it altogether. Article 12 submitted as follows; members of the League agree that if any disagreement arises between them that may lead to a rupture they will submit the issue to either a judicial settlement or arbitration or the council's inquiry and they agree not to resort to war until three months after the Council's report, or after the arbitrators award, or the judicial decision. ${ }^{18}$

The 1920s attempts to transform the Covenant's partial curtailing of war to a total ban by the Kellog-Briand Pact, resulted to the general treaty of war renunciation signed in 1928 which in Article 1 asserted that the high contracting parties in the names of their respective peoples solemnly declare that they condemn recourse to war as a solution of international disagreements and renounce it as a tool of national policy in their kind of relations. The Kellog-Briand Pact, and the League could not suppress wars in total since in the 1930s totalitarian aggression by Italy and Germany led to World War Two.

This discussion shows that state sovereignty coexisted with the principle of UHI ever since the state system was incepted. In 1955 a certain international lawyer wrote that there is a substantial body of practice and opinion of the view that when a state renders itself guilty to shock man's conscience and to the persecution of its own citizens intervention in

17 Fenwick, C. G.: Intervention: Individual and Collective. American Journal of International Law, 39 (1945), 645, 650.

18 Franck, T. M.: Of Gnats and Camels: Is there a Double Standard at the United Nations? American Journal of International Law, 78 (1984), 811, 825. 
the interest of humanity is permissible by law. A number of scholars however, dismissed such existence of a customary right. They had now to turn to interpretation of existing state practice which is then influenced by researchers' conviction whether intervention should be lawful or not. ${ }^{19}$

Other scholars however, submit that the correct position is that UHI was legal under customary law before the UN was established. Fonteyne ${ }^{20}$ asserts that while there was diverse opinions on what circumstances UHI was to apply, the principle in itself was widely accepted as a critical part of international customary law. It can be argued that by World War Two, this right already existed.

\section{The United Nations Charter-Treaty Law}

The basic regime in treaty law that governs the use of force is what is established in the UN Charter. The starting point on any argument on the legality or otherwise on the use of force in international law is enshrined in article 2(4) of the UN Charter. It provides that all members shall refrain from the use or threat of force in their international relations against the political independence or territorial integrity of any state or in any other way inconsistent with the purposes of the $\mathrm{UN}^{21}$

There are only two exceptions to the above clause of the UN Charter. The first is enshrined in article 51 that allows states to use force in self defense when faced by an armed attack. Chapter 7 of the Charter also allows the Security Council to express permission to use force against any member states if they believe that other measures that do not involve the use of force would not be adequate in the restoration or maintenance of international security and peace.

The ban on the use of force enshrined in article 2(4) is harmonized by article 2(7) of the UN Charter that prevents the UN itself from interfering in matters that are in essence within the domestic jurisdiction of any state. The puzzle here is in the UN Charter's article 2(7) and 2(4) if really there exists the right of humanitarian intervention in the Charter regime itself by virtue of the semantics in the articles themselves. The issue is whether collective or individual humanitarian intervention is legal if not authorized by the Security Council under the UN Charter. The Charter itself highlights the significance of equality, sovereignty and independence of individual states on one hand, while castigating the international community on the need to ensure that there is peace and stability in the entire world on the other. ${ }^{22}$

Most scholars in international law are of the view that humanitarian intervention is illegal under the UN Charter. These scholars point out that article 2(4) cannot be interpreted in another way to allow humanitarian intervention and that as the UN Charter provisions stand as of now, humanitarian intervention is illegal. Others hold that the principle of nonintervention has been raised to a status known in international law as ius cogens, a

19 Sornarajah, M.: International Colonialism and Humanitarian Intervention. Georgia Journal of International and Comparative Law, 11 (1981), 45, 57.

${ }^{20}$ Fonteyne: op. cit.

${ }^{21}$ Burmester, B.: On Humanitarian Intervention: The New World Order and Wars to Preserve Human Rights. Utah Law Review, (1994) 269, 278.

22 Douglas, E.: Humanitarian Intervention in the Post-Cold War Era. Boston University International Law Journal, 11 (1993), 195, 202. 
peremptory norm of general application where no derogation is allowed. Others argue that humanitarian intervention is legal since one of the key tenets of the UN Charter is to promote the respect of fundamental human rights.

\subsection{Classics Good Faith View}

Classics assert that there is no ground of persuasion for one to claim that there is a provision of humanitarian intervention under the UN Charter. They go on to point out that there are only two clauses barring the use of force as spelt out by the Charter; these are that of the Security Council authorization and asserting of self-defense. The provisions of Article 2(4) in conjunction with those in Article 2(7) pooled with General Assembly resolution 2131, totally abolishes the use or threat of force in international relations apart from the above two exceptions. Thus, classics conclude that the Charter forbid the use of force for humanitarian. (The classics are the Security Council authorization and asserting of selfdefense).

Secondly, they point out that the UN Charter framers explicitly and expressly made two exceptions to the overall prohibition on the use of force. The first is where the use of force is allowed in self defense in cases of armed attacks, while the second one is allowed to be used by the Security Council as an enforcement measure in carrying out its duties of restoring peace and order worldwide. Gordon, ${ }^{23}$ in support of these assertions, argues that if the framers of the UN Charter wanted to prevent the use of force on humanitarian grounds as a third exception, they would have expressively done so. Since the term humanitarian intervention cannot be seen anywhere in the Charter, this indicates expressly that there is no mandate to use force for humanitarian objectives.

Thirdly, classics rely on two general assembly resolutions to castigate the use of force. The first one is the general assembly resolution 2625 U. N. G. A. Res. 2625 (XXV) on the declaration of principles of international law concerning cooperation and friendly relations between states. The Charter states that no state or group of states has the right to intrude directly or indirectly for any reason whatsoever in the external or domestic affairs of another state.

They secondly rely on the 1974 General Assembly Resolution which defined aggression as the use of armed force by a nation against the political independence, sovereignty and territorial integrity of another nation. It categorically states that no justification whatsoever be it military, political, economic or otherwise may justify aggression. Scholars opposing the legality of humanitarian interventions pointed out that the General Assembly 1970 Resolution was a confirmation of the sacredness of the nonintervention principle and its dominance on international relations. ${ }^{24}$

Fourthly, classics support their argument against the right to use force on humanitarian grounds on the stipulations in the charter regarding using force in self-defense. They assert that framers of the Charter were so sceptical and fearful on the unilateral use of force that they had to limit the right to self defense. They base this on the fact that if an aggression is taken in self-defense, the Security Council must be immediately informed by the aggrieved state. As soon as the Security Council takes measures in respect to the attacks, the right to self-defense comes to an end. They argue that the right to launch an aggression is severely

23 Gordon: op. cit.

24 Francis, A.: The Evolution of the Doctrine and Practice of Humanitarian Intervention. The Hague, 1999. 
curtailed even in self-defense which has been legitimized under the Charter. It is thus prudent to prevent any use of force that is not provided for by the Charter expressly.

Finally, classics point out that the framers of the Charter clearly used the phrase against the political independence or territorial integrity of any state to buttress and not restrict the ban on using force in international relations. Thus, aggression on humanitarian grounds is clearly illegal under this Charter. ${ }^{25}$

\subsection{Realists Good Faith View}

On the other hand, realists feel that the establishment of the UN did not abolish the customary law of humanitarian intervention but rather, it emphasized and extended on the right to intervene on humanitarian grounds. They support their stand using articles that are relied on by scholars on the other side of the divide. Firstly, they assert that article 2(4) exclusion of the use of force is not universal in that it only curtails the use of force if it is directed towards the political independence or territorial integrity of a nation.

The loss of territorial integrity means ceding part of a portion of one's state permanently. Proper humanitarian intervention will not result in the loss of even a chunk of a state's sovereignty even if it is temporarily. The state of political independence submits that a nation's independence cannot be compromised. In the same breath humanitarian interventions would not impact on a country's independence and thus, does not violate a state's political independence.

\section{Interventions after the Cold war 1990 to present - Selection of Cases}

There were changes witnessed in the functions of the international community from the early 1990s. The changes were very profound and no one would imagine them a few years earlier. The collapse of the Soviet Union together with its Eastern bloc brought to an end to the East-West hostilities thus leading to the creation of a new international political climate. The Security Council was finally able to function as planned by the drafters of the UN Charter who wanted to achieve two objectives; encouragement, security and promotion of fundamental human rights and freedoms as well as the maintenance of international security and peace.

\subsection{France, USA and UK in Iraq 1991}

The Kurdish population of Iraq has, for a long time, asserted its legitimacy to sovereignty since the 19th century. However they are divided between Turkey, Iran, Syria and Iraq. They have since been persecuted by all the four countries at one time in history. In 1985, Saddam Hussein carried out atrocities against Kurdish villages killing 10,000 of them. In the Persian gulf war of 1991 Kurdish rebels capitalized on the military aggression of the US and its allies and made some tremendous military advances. There advances were however short lived when Iraq forces attacked them, killing many of them in the mayhem that followed. The 1.5 million of the Kurdish populace fled to Iran and Turkey. Subsequently on 3rd April 1991, the Security Council unanimously passed resolution 668 where it condemned the reprisals against the Iraq civilian population and demanded that Iraq should

${ }^{25}$ Fairley,S.: State Actors, Humanitarian Intervention and International Law: Reopening Pandora's Box. Georgia Journal of International and Comparative Law, 10 (1980), 29. 
immediately stop the mayhem in order to remove threats and facilitate international security and peace in the region.

While the resolution was referred to as a threat to international security and peace, it fell short of authorizing forceful measures via chapter 7 of the UN Charter. It does not expressively call for military intervention neither does it call for any collective enforcement measures. The text being a compromise was passed with limited support and was never accepted by the Soviet Union or China.

Nevertheless, later in April, the US, France and UK announced plans for an operation to provide comfort where it established no-fly zones and safe havens in Northern Iraq. Perez de Cuellar, the UN secretary General of the time, was concerned that without Iraq's consent they had the right to complain of violation of their sovereignty and felt that this aggression should have been sought from the Security Council. Despite this, the proposed aggression of the US and its allies started on April 16th and according to the US President, this aggression was motivated by a concern for humanity. This was acknowledged by the UN secretary General who supported their actions for acting on humanitarian grounds. Douglas Hurd, the UK foreign minister asserted that their actions were in line with the international law, adding that not all their actions had to be in the provisions of the UN Charter so long as they act within the provisions of the international law which does recognize extreme humanitarian needs.

However, shortly after the intervention, the US and its allies tried to drop the responsibility of the aggression under the UN Security Council. There was a need of consent from Iraq to make it legal and by April 18, Iraq signed a deal with the UN allowing a limited number of UN troops to act as guards on its soil in addition to the creation of 100 civilian aid centers in Iraq. Scholars such as Lieblich, argue that the aggression was through the consent of Iraq and was therefore legal. ${ }^{26}$ However, this paper argues that the aggression was not legal given that Iraq was forced to accept a limited number of UN troops after the US and its allies had invaded it. The initial aggression was under humanitarian grounds.

Apart from that, scholars argue that resolution 688 of the UN Charter in itself did not provide a legal impetus for this aggression. The legal significance of the actions by the US and its allies as far as state practice is concerned in the development of customary international law would only be understood in a long-term perspective. ${ }^{27}$

The allied aggression in Northern Iraq can thus be summed up as a case of intervention on humanitarian grounds. Though, the Allied Forces members made statement that they protect the people ${ }^{28}$ to justify their interventions on grounds of humanity but they never officially justified this intervention. The legal counsel, in a memorandum to the British Foreign Minister, stated that the aggression in northern Iraq was not sanctioned by the UN as such but the Allied Forces did so under the mandate of the principle of humanitarian

${ }^{26}$ See Lieblich, E.: International and consent: consensual forcible interventions in internal armed conflicts as International agreements. Boston University International Law Journal, 29 (2011), $337-382$.

${ }^{27}$ Fonteyne, J.: The Customary International Law Doctrine of Humanitarian Intervention. California Western International Law Journal, 4 (1974), 203, 257.

28 On 17 April 1991, armed forces of the United States and other countries began to move into northern Iraq with the declared aim of setting up camps to secure the safety of Kurdish refugees and of coordinating relief supplies. As stated by the President of the United States, the intention was 'to turn over the administration of, and security for these sites as soon as possible to the UN, see Keesing's Record of World Events, 37 (1991) 38, 127. 
intervention in the international customary law. Similar statements and sentiments were expressed by US officials. ${ }^{29}$

Since these statements were never made officially, it means that the allied nations never viewed the principle of humanitarian intervention as legal at that point in time, members of the Security Council. It is, however, argued that by they keeping silence tactfully at that point in time, were in essence acknowledging the doctrine and thus, accepting that such rules were part and parcel of customary law. It is alleged that China and the Soviet Union did not support the resolution that permeated the use of force since they did not want to set a precedent of limiting the sovereignty of other nations.

However, this paper argues that it would be wrong to conclude that the inaction of the Security Council members during the aggression was a tactful move to consent to the aggression by the Allied Forces. The UN Security Council should explain the legality of humanitarian intervention rather than their failure to protest the aggression since the use of veto makes the UN toothless at times. Therefore, the Northern Iraq intervention cannot be perceived as legal for rendering intervention on the basis of humanity under the auspices of the international customary law.

\subsection{NATO in Kosovo - 1999}

On 21st of November 1995, when the final ink to paper signature was made, signaling the end of hostilities in the Bosnia war, many people thought the war had ended. This dream was never to be when Slobodan Milosevic, the Yugoslavian President suddenly meted out atrocities against the Kosovo-Albanians (Kosovars) by suspending their rights as spelt out in the 1974 FRY constitution and came up with a strict segregation policy which has been described by some scholars as an apartheid system. ${ }^{30}$

In the second and third quarters of 1996, the Kosovo Liberation Army (UCK) began seeking international attention to the polarized situation in their country. According to them, the pacifist boycott policy was making their plight worse by securing Serb control in a region whose $90 \%$ of inhabitants were Albanians. The FRY army increased their attacks on the UCK, thereby intensifying the conflict. However, it was not until 1998 that the international community decided to meddle in the affairs of this region. ${ }^{31}$

On March 31st 1998, the members of the Security Council voted overwhelmingly for resolution 1160 where they condemned the use of excessive force by the Serbian police against innocent civilians who were peacefully demonstrating in Kosovo. They also condemned the terrorism acts by the Kosovo liberation army. This resolution while not prescribing any solution to the conflict, did impose a weapon embargo and called on the conflicting parties to settle their issues through dialogue. ${ }^{32}$

${ }^{29}$ Nanda, V. P.: Tragedies in Northern Iraq, Liberia, Yugoslavia, and Haiti-Revisiting the Validity of Humanitarian Intervention under International Law-Part I. Denver Journal of International Law, 20 (1992), 305, 320.

30 Simma, B.: NATO, the UN and the Use of Force: Legal Aspects. European Journal of International Law, 10 (1990) 1, 5.

${ }^{31}$ Kritsiotis, D.: The Kosovo Crisis and NATO's Application of Armed Force Against the Federal Republic of Yugoslavia. International and Comparative Law Quarterly, 49 (2000), 330, 337.

32 Farer, T. J.: The Regulation of Foreign Intervention in Civil Armed Conflict. Recueil des Cours, 142 (1974) 291. 
The hostilities intensified and it was discovered that the fleeing Kosovo civilians were finding their way into Macedonia and Albania. Subsequently on September 23rd 1998 the Security Council passed resolution 119 which affirmed that the situation in Kosovo and Yugoslavia constituted a threat to peace and stability in the region and thus demanded that the authorities of the two countries take immediate action to avert the impending humanitarian crisis and improve the humanitarian situation. As much as the situation was regarded at that point in time, as a case filed under chapter 7 of the UN Charter, the demands provided for under this resolution were not backed by military action. It was not feasible to come up with an express decision to use force since Russia and China would veto such a proposal. $^{33}$

The hostilities went on unabated and the humanitarian situation worsened. At this point in time the NATO alliance decided to take action. On the $13^{\text {th }}$ of October 1998, they gave a warning of impending air strikes if the Serbs did not cease attacking Kosovo settlements. They, however decided to send US special envoy Holbrooke to Belgrade, who persuaded Milosevic to stop the aggression and allow into the country inspectors from the Organization on Security and Cooperation in Europe (OSCE). This led to a temporary cease fire. ${ }^{34}$

The temporary ceasefire came to an abrupt end when the UCK/KLA, ${ }^{35}$ which did not participate in the OSCE agreement, refused to honor it. In retaliation, FRY forces killed 45 civilians in Racac village shocking the international community. NATO later invited the protagonists to a last minute meeting to secure peace in Rambouillet, Paris. In this meeting, the UCK/ KLA agreed to drop the demand for total sovereignty while the FRY accepted a NATO force in Kosovo. The Serbs did not accept these terms and started an ethnic cleansing of Kosovo. Milosevic refused to oblige even when NATO made a last minute plea for a peaceful resolution to the conflict. Consequently, NATO began the launch of airstrikes on 23rd March 1999.

Possible justifications for NATOs interventions as provided by Scholars such as Simma ${ }^{36}$ include; the credibility of NATO as a collective defense organization was being questioned. But this cannot be a legal justification for waging war in the international customary law. It, therefore, has no basis as far as the legality of NATO's humanitarian intervention in Kosovo is concerned. ${ }^{37}$

Secondly, some scholars argue that it was a Security Council Resolution, but since China and Russia opposed it in the Security Council and as a fait accompli, it then becomes an evident misconception. The rationale that sought to justify their actions on grounds of humanity is the one that has generated the most debates. It was projected that their action was meant to avert an impending catastrophe and thus, is the only way that their intervention can possibly be termed as legal. The British Foreign Secretary asserted in the parliament that at that point in time, they were not left with any alternative but to go to war in order to

33 Cassese, A.: Ex Iniuria Ius Oritur: Are We Moving Towards International. Legitimization of Forcible Humanitarian Countermeasures in the World Community? European Journal of International Law, 10 (1999), 23, 24.

34 Cassese: op. cit.

35 Known as "KLA", "Kosovo Liberation Army".

36 Simma: op.cit.

37 O'Connell, M. E.: The UN, NATO, and International Law after Kosovo. Human Rights Quarterly, 22 (2000), 57, 82. 
prevent Milosevic from doing more atrocities in Kosovo that would have led to a serious catastrophe. ${ }^{38}$

The significance of this intervention, as regards the unilateral humanitarian intervention, can be drawn from reactions of the international community preceding the action. Most western states supported NATO for taking this action. As a matter of fact, Britain reiterated its earlier justification of the Iraq inversion and asserted that humanitarian intervention is legalized in the international customary law. ${ }^{39}$

On the other hand, China termed this invasion as gunboat diplomacy. Russia termed it as a question of law and lawlessness. Following this intervention on March 26th 1999, Russia, while being supported by India and Belarus, presented a draft resolution to condemn the Kosovo intervention as unlawful under the UN Charter. This draft was defeated by a vote of 12 to 3 . Surprisingly, amongst the 12 were 6 non-western countries. For the first time since its inception, the SC did not vote to condemn unilateral humanitarian intervention. More so, the UN Secretary General Kofi Annan also showed limited support for the intervention when in 1999 he stated that "On one hand, is it legal for a regional organization to use military force without the mandate of the UN? On the other hand, is it justifiable to let systematic atrocities against humanity continue unabated?"

No strong opposition emerged from a majority of the member states of the UN Security Council. The legal importance of the case comes from the fact that it was no longer just the exaggeration of lawyers sympathetic to the working of humanitarian interventions rather the actual practice and working of states as expressed in the UN forum that supported the principle of humanitarian intervention.

\subsection{The Allied Forces in Libya - 2011}

The UN Security Council resolution 1973-2011 authorized member states, acting through regional organizations or alone, to take all steps deemed fit to protect citizens under attack from Muammar Gadhaffi's forces. In resolution 1970 (2011), the UN Security Council had expressed its concerns about the escalating violence in Libya and the use of military action against civilians in that nation. It also deplored the systematic and gross violations of human rights which included the repressions of peaceful demonstrators showing deep concerns for the deaths of innocent civilians and unequivocally rejecting the incitements to violence and hostilities against the civilian population made by holders of state power in the Libyan government. Members of the Security Council who voted for this resolution were clear that it was made solely for humanitarian concerns in order to protect civilians from more harm since Muammar Gadhaffi was about to launch more attacks in the opposition strongholds in the Eastern parts of Libya.

After resolution 1973 was passed, military action led by the US, the UK, France and NATO commenced. Military intervention in Libya is believed to be legal since it was sanctioned by the Security Council under section 7 of the UN Charter. But other scholars contend that this action by the UN Security Council was illegal given that there was no deployment of UN troops on the ground as peace keepers. In any case, it is the General

${ }^{38}$ Lillich, R. B.: The Role of the UN Security Council in Protecting Human Rights in Crisis Situations: UN Humanitarian Intervention in the Post-Cold War World. Tulane Journal of International and Comparative Law, 3 (1994) 1, 2.

39 Geissler, L.: The Law of Humanitarian Intervention and the Kosovo Crisis. Hamline Law Review, 23 (2000), 323, 325. 
Assembly rather than the Security Council that has legitimacy to sanction any humanitarian interventions in areas it deems fit. ${ }^{40}$

On the other hand, scholars who support the UN SC resolution in Libya such as Modeme and Schmitt assert that the UN Charter has no legal provisions to express humanitarian interventions. ${ }^{41}$ However, it is presumed that the UN Security Council may sanction such actions and it has indeed sanctioned humanitarian interventions in the past. For instance in Somalia in 1992, under Security Council resolution 794, it requested all its member states to act as soon as possible with all necessary means at their disposal to establish a safe environment for humanitarian relief operations in the war torn country. In Bosnia Herzegovina of the same year, the UN Security Council under resolution 770 asked all member states to act by all means possible to establish a safe corridor for the transfer of humanitarian relief food to the victims of the war. In 1994 the UN Security Council under resolution 929 asked member states to act by all means possible to facilitate the transfer of humanitarian assistance to the region.

The Security Council may only be acting legally if it satisfies the following conditions; intervening on humanity grounds and if the preceding situation that gives rise to a humanitarian crisis is a threat and breach of international security and peace. Such situations could necessitate the application of force within or without the concerned nation as provided in chapter 7 of the UN Charter. Article 39 of the UN Charter gives the Security Council authority to determine whether an act of aggression, threat to regional and international peace or a breach of peace exists and come up with recommendations to remedy the situation through maintaining international peace and security. This provision aligns itself to article 1(1) of the UN Charter which states that the first objective of the UN is to facilitate international security and peace for which purpose it has the right to take collective measures for the removal and prevention of threats while suppressing other breaches or acts of aggression to the peace.

\section{Conclusions}

The principle of humanitarian intervention is significant and morally necessary in the world today. It is unjustifiable to let human beings die unabated under atrocities committed by their leaders. It is unfortunate thus that the rules of the present international law do not allow unilateral humanitarian interventions.

This paper must quickly point out that as far as the doctrine is meant for good if proper mechanisms are not put in place for regulation purposes, the meaning of humanitarian intervention may be misunderstanding. Regardless of possible misunderstanding, thus, principle is very critical as far as the protection of fundamental human rights and the maintenance of world peace are concerned. However, an appropriate mechanism should be enacted to regulate it.

40 Modibo Ocran, T.: The Doctrine of Humanitarian Intervention in Light of Robust Peacekeeping., Boston College International and Comparative Law, 25 (2002) 1, 14-15.

${ }^{41}$ Modeme, E. L.: The Libyan Humanitarian Intervention: Is it Lawful in International Law. (2011) available at: http://www.academia.ed, accessed on 22-3-2013; Schmitt, M.: (2011) Wings over Libya: The No Fly-Zone in Legal Perspective. Yale Journal of International Law, 36 (2011) 45-85, 48 . 
The best way to come up with a system that guarantees the principle is not just maintained but is also regulated by amending the UN drafted guidelines concerning humanitarian interventions. Provisions of the UN Charter should be amended to allow for humanitarian intervention after certain conditions are met. This paper acknowledges that it could be difficult to get a consensus at the UN concerning this issue since most states prefer absolute sovereignty but the difficulty cannot be insurmountable.

Therefore, this paper suggests that for any coherent theory that seeks to regulate UHIs, the first thing to do for a state contemplating UHI is to inform the Security Council. It is only after the Security Council fails to act on the situation within reasonable time should a state decide to take action. Apart from that, it should be established beyond doubt that the violations in the targeted state are gross violations of human rights. This means that if the violations are not that serious no interventions should be warranted.

In addition to this, all measures that do not use force should be employed to stop the violations before contemplating military aggression. Also, the human rights records of the intervening state should be checked to ensure that states with bad record do not take part in UHI. Lastly, the duration of the intervention should be short enough to bring a quick end the violations. 